\title{
ПЕТРОЛОГИЯ, ВУЛКАНОЛОГИЯ
}

УДК 551.2:552.321 (470.5)

\section{Новые данные по минералогии и петрогеохимии щелочных пород козлиногорского комплекса (Уфалейский блок, Средний Урал)}

А.И. Белковский ${ }^{1}$, Г.Ю. Шардакова ${ }^{2}$, В.В. Холоднов ${ }^{2}$, В.Н. Удачин ${ }^{1}$, Е.В. Коновалова ${ }^{2}$

${ }^{1}$ Институт минералогии УрО РАН, 456317, Миасс, ул. Ильменский заповедник, кор. 1

${ }^{2}$ Институт геологии и геохимии УрО РАН, 620016, Екатеринбург, ул. акад. Вонсовского, 15. E-mail: shardakova@igg.uran.ru

(Статья поступила в редакиию 17 сентября 2017 г.)

Щелочные комплексы, продуктивные на редкие металлы, на западном склоне Урала довольно редки. Породы козлиногорского комплекса приурочены к Уфалейскому блоку, находящемуся в зоне сочленения Урала и ВосточноЕвропейской платформы. Комплекс представлен габбро, сиенитами, граносиенитами и гранитами. Их щелочная специфика определяется наличием эгирина, рибекита, астрофиллита, энигматита. Породы характеризуются соотношениями редких элементов и особенностями флюидного режима, указывающими на участие в их генезисе мантийного плюма. Последний мог быть энергетическим и вещественным источником, инициирующим процесс растяжения в древних рифтовых структурах. Щелочные плюм-зависимые серии все чаще фиксируются на западном склоне Урала, указывая на существенную роль плюм-тектоники в геодинамике ранних этапов развития структуры.

Ключевые слова: щелочные комплексы, редкометалльное оруденение, рифтогенез, анорогенные граниты, петрогеохимия, плюм-тектоника.

DOI: 10.17072/psu.geol.17.4.308

\section{Введение}

Щелочные гранитоиды древнего возраста, несущие редкометалльную минерализацию, на Урале достаточно редки (Золоев и др., 2004). Изучение их петрологии, минералогии и геохимии является важным способом получения информации о специфике составов, геодинамических условиях образования и потенциальной рудоносности (на $\mathrm{Nb}, \mathrm{Zr}, \mathrm{Th}, \mathrm{U}$ и др.). Целью настоящей работы является анализ авторских и литературных данных о геологических, минералого-петрографических и геохимических особенностях и ге- незисе щелочных гранитоидов Уфалейского блока, расположенного в зоне аккреции между Уралом и ВосточноЕвропейской платформой (ВЕП). Полученный материал вносит вклад в изучение и типизацию щелочных пород Урала и его обрамления, способствует уточнению геологической истории этой сложной гетерогенной области.

\section{Геологическая позиция}

В начале XX в. Д.С. Белянкин в 4 км на юг от поселка Нижний Уфалей на горах Козлиных описал редкие для Средне(С Белковский А.И., Шардакова Г.Ю., Холоднов В.В., Удачин В.Н., Коновалова Е.В., 2018 
го Урала граниты с высокими содержаниями фиолетового флюорита (Белянкин, 1933). Они также были исследованы В.А. Махининым и Г.А. Смирновым, которые впервые отнесли их к группе щелочных гранитов (Смирнов, 1956). В качестве темноцветных минералов в гранитах отмечались эгирин и амфибол, по оптическим свойствам близкий к гастингситу. Позднее (1971) данные по минералогии и химическому составу пород и металлогенические характеристики подтвердили щелочную специфику козлиногорских гранитов, что позволило впервые на Урале выделить щелочные граниты с астрофиллитом, эгирином, рибекитом (Белковский, Локтина, 1974). Тела гранитоидов, обозначенных в названии статьи, располагаются на территории Нязепетровского, Уфалейского, Кыштымского и Карабашского районов Челябинской области. На современных геологических картах (2009) они объединяются в козлиногорский комплекс (КГК), локализованный в пределах Уфалейского метаморфического блока (УБ) и его ближайшего западного обрамления. УБ является крупной частью Центрально-Уральского поднятия.

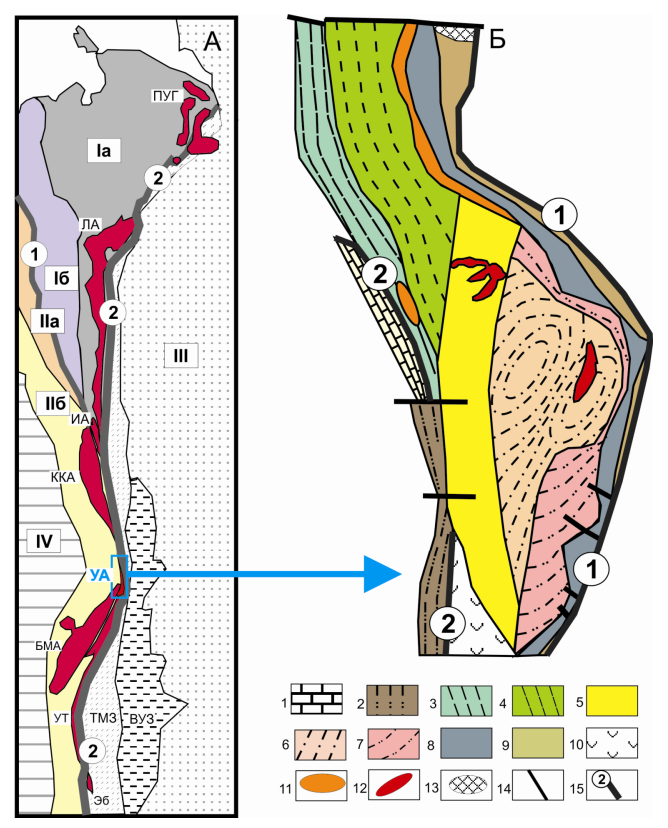

Рис. 1. Тектоническая схема Урала (А) и Уфалейского метаморфического блока (Б) (Кузнеиов и др., 2005; Белковский, 2011; Пучков, 2012): А. Зоны разломов (цифры в круж- ках): 1 - Припечоро-Ильч-Чикшинская зона, 2 - Главныий Уральский разлом. ТМЗ - ТагилоМагнитогорская мегазона; ВУЗ - ВосточноУральская мегазона. Блоки с древним фундаментом: ПУГ - Полярно-Уральская группа, включаюшая поднятия: Хараматалоу, Собское (с Енганепэ, МанитанырдПайпудынским и Харбейским выступами), Оченьрдсккое; ЛА-Ляпинский антиклинорий; ИА - Ишеримский антиклинорий; ККА Кваркушиско-Каменногорский антиклинорий; УБ - Уфалейский блок; БМА - Башкирский мегантиклинорий; УТ - Уралтау; Эб - Эбетинская антиформа. Большеземельская зона: Iа - Большеземельский и Іб - Печорский мегаблоки; Тиманская зона: Іа - Ижемский и Іб - Тиманский мегаблоки; III - ВосточноЕвропейская и IV - Западно-Сибирская платформит.

Б. Мерзелинская пластина: 1 - известняки, доломитизированные известняки (нижний рифей, саткинская свита ?). Златоустовский комплекс: 2 - глиноземистые сланць с хлоритоидом и ставролитом, таганайская свита (ср.рифей). Указарская пластина $(3,4): 3$ - зеленосланцевые бластомилониты с телами титан-авгитовых пироксенитов, керсутитового габбро, амфиболового метагаббро, щелочных гранитов А-типа; 4 - микрогнейсы альбитовые, альбит-микроклиновые фенгитсодержащие. Егустинская пластина (5-7): 5 - апогаббровые бластомилониты, сиенитмигматиты и сиениты; 6 - апогаббровые амфиболиты с телами метагаббро-норитов, метагабброидов; 7 - апогаббровые амфиболиты, гранитные пегматиты слюдоносные и редкометалльные, плагиоклазитьы, сиениты, щелочные гнейсограниты и карбонатитыл. Куртинская пластина (8, 9): 8 - эклогитсланцевый мегамеланж, 9 - низкобарические бластомилониты. 10 - амфиболиты апогаббровые с телами офитового габбро (Рассыпухинский комплекс); 11 - щелочные сиенитоиды и граниты козлиногорского комплекса (ордовик); 12 - граниты палеозойского уфалейкинского (запад егустинской пластины) и венд-кембрийского битимского комплексов (восток); 13 - антигоритовые серпентиниты; 14 - мелкие разрывные нарушения; 15 - разломы, ограничивающие Уфалейский блок, иифрры в кружках: 1 - Главный Уральский разлом; 2 - ЮрюзаноЗюраткульский разлом 
Восточная граница - Главный Уральский разлом, отделяющий УБ от эффузивно-осадочных образований Тагильской зоны. Западная граница проходит по Юрюзано-Зюраткульскому разлому, западнее которого развиты метаосадочные породы таганайской свиты $\left(\mathrm{Rf}_{2} t g\right)$, относящиеся к Златоустовскому комплексу северо-восточной части Башкирского мегантиклинория (Пучков, 2012).

Последними геолого-съемочными работами (2009) подтверждено, что в состав серии пород, формирующих КГК, входят габброиды, сиениты, граносиениты, граниты. Их типизация обсуждается в соответствующем разделе статьи. Породы образуют ряд малых линейно вытянутых интрузивных тел, согласных (реже - секущих) с вмещающими метаморфическими породами (рис. 1) в западной и восточной частях УБ. Кроме того, тела гранитоидов, также относимых к КГК, секут породы таганайской свиты западнее Юрюзано-Зюраткульского разлома (западный ареал) и описаны в ряде работ (Золоев и др., 2004; Тевелев и др., 2015).

На площади распространения КГК был зафиксирован геохимический ореол $\mathrm{Nb}, \mathrm{Sn}, \mathrm{Pb}, \mathrm{Cu}, \mathrm{Bi}, \mathrm{Mo}$, подтверждена потенциальная продуктивность на редкие металлы. $\mathrm{Zr}-\mathrm{Nb}$ минерализация здесь была открыта Агардяшским отрядом ЧГРЭ в 1969 г. и в ходе работ подробно изучена А.И. Белковским в 1971г. Повышения концентраций $\mathrm{Nb}$, Ta, $\mathrm{Zr}$, Th и рудные скопления фиксируются в приконтактовых фенитах.

\section{Обзор существующих представлений}

Долгое время считалось, что большая часть УБ занято крупной гранитной интрузией, над которой в качестве пород кровли присутствуют амфиболиты, парагнейсы и кристаллосланцы. Гнейсовомигматитовая природа большинства образований УБ установлена П.П. Скабичевским (1940). По результатам геологосъемочных работ (1951-1961) блок рассматривался как антиклинорная структу- pa, нижний структурный этаж которой представлен допалеозойским гнейсомигматитовым ядром, верхний блок - более молодым палеозойским сланцевым обрамлением. Согласно точке зрения Г.А. Кейльмана (1974) и авторов данной работы, в ядре УБ расположены апогаббровые амфиболиты, которые в процессе гранитизации превращены в амфиболовые, биотит-амфиболовые гранито-гнейсы с разным соотношением лейкократовой и меланократовой частей (на старых геологических картах - уфалейская свита). Ортопороды основного состава (амфиболиты) из центральной и восточной частей УБ несколько различаются по минеральному составу и уровню метаморфизма. Принципиальным различием в химическом составе служат содержания $\mathrm{TiO}_{2}$. В работе В.А. Коротеева и др. (2010) показано, что богатая иттровая минерализация, сосредоточенная в юго-востоной части УБ, связана с возможной мобилизацией $\mathrm{Y}$ из амфиболитового субстрата с последующим отложением в более кислых разностях. Считается, что и осадочный субстрат мог играть некоторую роль при формировании пород гнейсовомигматитового ядра УБ. Восточная часть УБ представлена сильно деформированными кристаллосланцами (куртинская свита).

На современной геологической карте подразделение на свиты несколько более дробное; некоторые из них имеют другие названия (егустинская и слюдяногорская свиты - ядро УБ), однако общие представления и структурный план в целом отвечают охарактеризованным выше представлениям.

Детальное изучение (Белковский, 2011) геологических, минералогических и петрологических данных позволяет утверждать, что УБ сложен рядом тектонических пластин (с запада на восток), различающихся составом, генезисом, степенью метаморфизма и возрастом слагающих их образований (рис. 1):

1) мерзелинская пластина - мраморизованные известняки (саткинская свита?); 
2) указарская - зеленосланцевые бластомилониты (венд и древнее) с телами титан-авгитовых пироксенитов, керсутитового габбро и раннепалеозойских щелочных гранитов А-типа;

3) егустинская - метагабброиды, апогаббровые амфиболиты и плагиогранитогнейсы (венд-палеозой??) с телами ордовикских граносиенитов, сиенитов и гранитов;

4) куртинская пластина - эклогитсланцевый мегамеланж: высокобарические гранат-фенгит-кварцевые и гранатмусковит-кварцевые бластомилониты (палеозой) с телами гранатовых пироксенитов, эклогитов и апоэклогитовых амфиболитов; низкобарические высокоглиноземистые бластомилониты.

Возраст пород, слагающих данные пластины, здесь приведен (в скобках) на основе K-Ar и Ar-Ar определений по минералам и представлений А.И. Белковского $(2006,2011)$ и, вероятно, большей частью отражает возраст метаморфизма; ряд этих данных требует уточнения более современными методами.

В целом история геологического развития УБ длительная и сложная. На это указывает степень дислоцированности толщ, разнообразие составов магматических пород и Р-Т условий их преобразования. Поэтому геодинамическая природа УБ до сих пор трактуется по-разному. Он считается либо чуждым террейном (Нечеухин, Краснобаев, 2000), либо фрагментом края ВЕП (Иванов, Русин, 2000 и др.), оторванным от нее и потом причлененным заново. Возрастные этапы эволюции и возможные геодинамические обстановки в УБ можно проследить по эволюции имеющихся здесь гранитоидных серий (Шардакова, 2017). Она включает следующие этапы: 1) континентальный рифтогенез (1100-900 млн лет) (ортопороды кислого состава из всех «пластин» УБ); 2) повторный импульс рифтогенеза с подновлением рифтовых трещин (либо краткий эпизод орогенной активности?) (570533 млн лет, Никольский массив, битимский комплекс); 3) ранний орогенез (317 млн лет, Нижнеуфалейский массив, уфалейкинский комплекс); 4) коллизионные события (260-250 млн лет, кизильский комплекс). На основе анализа изотопных данных показано, что имеет место вещественная эволюция субстрата во времени, отражающая нарастание доли сиалического компонента в источнике для выплавления гранитов.

Ранее, с точки зрения формационного анализа, было показано, что породы центральной часть УБ близки к образованиям контрастных серий кварцево-альбитофирдиабазовой формации (Кейльман, 1974). Позднее блок рассматривался в составе дорифейской базальтовой (трапповой?) формации (Ленных, 1980), формации ранневендских недифференцированных малоглубинных базальтов (Голдин, Калинин, Пучков, 1988). Гнейсовое ядро Уфалейского блока характеризуется однородным метаморфизмом верхних субфаций амфиболитовой фации и низших субфаций гранулитовой фации (Кейльман, 1974).

Породы, относимые к КГК, образуют линейно вытянутые секущие или согласные со структурным планом вмещающих пород тела, как правило, окруженные контактовым ореолом фенитов. При этом все интрузивные тела приурочены к разрывным нарушениям, наиболее крупные к активным и долгоживущим «шовным зонам» (Коротеев и др., 2010) (Главный Уральский и Юрюзано-Зюраткульский разломы). Рудной минерализацией $\mathrm{Nb}$ и $\mathrm{Zr}$ насыщены как сами породы, так и фениты (последние - в большей степени). Вблизи разломов породы КГК часто превращены в бластомилониты (см. ниже) и, по-видимому, подверглись существенному изменению химического состава.

Возраст КГК определялся разными методами (преимущественно K-Ar, Ar-Ar по минералам) и лежит в интервалах от 278-290 млн лет, 396-354 млн лет и до 440 млн лет (Белковский, Локтина, 1974; Белковский, Белковская, 2004; Золоев и др., 2004). Согласно последним определениям U-Pb возраста цирконов из габбро, 
субщелочных граносиенитов и гранитов КГК, датировки попадают в диапазон 480-450 млн лет (Шардакова и др., 2014; Тевелев и др., 2015), что соответствует раннему ордовику. Отметим, что более древние возрасты в цирконах не фиксируются, а молодые (этапы преобразований) отвечают возрасту палеозойских орогенных событий на Урале. Данные по изотопии $\mathrm{Rb}-\mathrm{Sr}$ и $\mathrm{Sm}-\mathrm{Nd}$ по породам КГК отсутствуют.

Некоторые данные по минералогии, петрографии и геохимии пород приведены в многочисленных работах (Белковский, Белковская, 2006; Шардакова и др., 2014; Тевелев и др., 2015), здесь мы комментируем результаты новых аналитических работ. Породы, характеризуемые ниже, большей частью приурочены к указарской пластине.

\section{Новые данные по петрографии и мине- ралогии}

Горными и геолого-петрографическими работами было выявлено, что гнейсовидные граниты (относимые к КГК) образуют пластовое тело, согласно залегающее среди зеленых сланцев указарской свиты, рассматриваемых нами как низкобарические бластомилониты дистен-андалузитовой фациальной серии. По простиранию субмеридиональное тело гнейсовидных гранитов горными работами прослежено на протяжении 2500м. Средняя мощность тела, вскрытого разведочными канавами, составляет 150-200 м. Падение тела восточное, под углами 25$30^{\circ}$. Изученное тело характеризуется зональным строением (характеристика разреза приводится с запада на восток): 10 м - микроклинизированные альбит-хлоритактинолитовые бластомилониты и крупнозернистые светло-розовые микроклиниты с чевкинитом - (Cе) и алланитом $(\mathrm{Ce}) \rightarrow 15$ м - биотитовые плагиогнейсыграниты $\rightarrow 80$ м - рапакивиподобные аннит-магнетитовые гнейсограниты $\rightarrow 15$ $20 \mathrm{~m} \mathrm{-}$ рапакивиподобные эгиринрибекит-астрофиллитовые гнейсограниты $\rightarrow$ 18-20 м - рапакивиподобные аннит- магнетитовые гнейсограниты, флюоритизированные и окварцованные, $\rightarrow 15-30$ м - микроклинизированные альбит-хлоритактинолитовые бластомилониты.

Из приведенного описания видно, что основной объем изученного тела представлен аннит-магнетитовыми гнейсогранитами. Структура пород в данном разрезе гранобластовая, гранопорфиробластовая. Под микроскопом на фоне основной массы выделяются своеобразные овоиды $(0.2 \times 0.6$ и $2.0 \times 4-5$ мм $)$ микроклинпертита в альбит-олигоклазовых каймах. Такие образования получили собственные названия - рапакивигранитные породы, широко распространенные в Салминском и Выборгском массивах рапакиви (Ларин, 2011). В целом среди пород, описываемых в составе КГК, встречаются разности с монцонитовой (сиениты) и реликтовой гранитной структурой, указывающей на первично магматическое происхождение.

По минеральному составу среди гранитоидов КГК выделено две разновидности: магнетит-аннитовые и эгиринрибекит-астрофиллитовые. Содержания микроклин-пертита, альбита и кварца в обоих типах приблизительно одинаковые (об. \%: микроклин-пертит - 30-35, альбит $\mathrm{An}_{10-20}-10-25$, кварц - 30-35, оранжевый аннит - 0-2), что обусловило их близкий химический состав. $\mathrm{B}$ магнетитаннитовых и эгирин-рибекит-астрофиллитовых разностях несколько различается состав породообразующих минералов железо-магнезиальных слюд, тетраферрифлогопита, магнетита.

Ниже описаны специфические щелочные минералы, встречающиеся в породах КГК и дающие основание считать вмещающие их породы щелочными. Химический состав минералов из пород КГК приведен в таблице.

Эгирин. Встречен только в ассоциациях с рибекитом в виде короткопризматических кристаллов светло-зеленого цвета (таблица, обр. 3). Размер индивидов по удлинению колеблется от 0.1-0.3 до 1.0 мм. Оптически отрицательный. $\mathrm{Ng}=$ $1.800-1.801 ; \mathrm{Np}=1.756-1.757$; двупрелом- 
ление - 0.043. Плеохроизм обычный: $\mathrm{Ng}-$ светло-зеленый, $\mathrm{Nm}$ - голубоватозеленый, $\mathrm{Np} \mathrm{-} \mathrm{зеленовато-синий,}$ $\mathrm{Ng}<\mathrm{Nm}<\mathrm{Np}, \mathrm{C}: \mathrm{Np}=0^{\circ}$.

Рибекит. Отмечен в виде длиннопризматических кристаллов $(0.2 \times 2.0 \mathrm{Mм}$ и до $0.5 \times 2.0 \mathrm{~cm})$, образует прерывистые полосы согласно разгнейсованности по- род (таблица, обр. 4). Оптически отрицательный. $\quad \mathrm{Ng}=1.698-1.700 ; \quad \mathrm{Np}=1.694$ 1.696; двупреломление - 0.004. Плеохроизм резкий, от темно-синего по $\mathrm{Np}$, синего - по Nm и до желто-грязно-зеленого по $\mathrm{Ng}$. C:Np=2 $2^{\circ}$ Рибекит замещает эгирин, в свою очередь сам замещается астрофиллитом и аннитом.

Химические анализы минералов из щелочных гранитов указарской пластины, мас. \%

\begin{tabular}{|c|c|c|c|c|c|c|c|c|c|c|}
\hline № & 1 & 2 & 3 & 4 & 5 & 6 & 7 & 8 & 9 & 10 \\
\hline $\mathrm{SiO}_{2}$ & Сл. & 35.33 & 51.80 & 48.82 & 35.26 & 35.41 & Сл. & 30.54 & 32.62 & 47.47 \\
\hline $\mathrm{TiO}_{2}$ & 0.95 & 4.07 & 0.10 & 1.10 & 8.20 & 2.76 & 0.63 & 35.51 & 0.00 & 0.40 \\
\hline $\mathrm{ZrO}_{2}$ & Сл. & - & 0.071 & - & 0.41 & 0.021 & - & 0.10 & 63.47 & - \\
\hline $\mathrm{SnO}_{2}$ & Сл. & - & - & - & 0.10 & - & - & 0.21 & - & - \\
\hline $\mathrm{Al}_{2} \mathrm{O}_{3}$ & 0.51 & 15.90 & 2.60 & 2.25 & 2.75 & 15.24 & 0.14 & 0.61 & 0.81 & 24.95 \\
\hline $\mathrm{Fe} 2 \mathrm{O}_{3}$ & 69.49 & 14.00 & 31.17 & 15.45 & 6.80 & 5.11 & 68.66 & 3.11 & 1.21 & 4.56 \\
\hline $\mathrm{Cr}_{2} \mathrm{O}_{3}$ & Сл. & Сл. & - & - & - & 0.002 & 1.700 & - & - & - \\
\hline $\mathrm{FeO}$ & 28.02 & 15.37 & 1.20 & 20.27 & 26.62 & 28.40 & 0.46 & 0.35 & 3.72 & 13.21 \\
\hline $\mathrm{MnO}$ & 0.21 & 0.28 & 0.05 & 0.04 & 2.48 & 0.84 & 0.33 & 0.09 & 0.04 & 0.10 \\
\hline $\mathrm{MgO}$ & 0.21 & 0.98 & 0.05 & 0.60 & 0.74 & 0.60 & 0.03 & 0.07 & 0.10 & 2.10 \\
\hline $\mathrm{CaO}$ & Сл. & 0.42 & 0.56 & 0.33 & 0.69 & 0.21 & Сл. & 25.31 & Н.обн. & 0.10 \\
\hline $\mathrm{BaO}$ & - & - & - & Н.обн. & Н.обн. & 0.51 & - & - & - & 0.06 \\
\hline $\mathrm{ZnO}$ & 0.13 & - & 0.05 & Н.обн. & 0.09 & 0.41 & 0.26 & - & - & 0.14 \\
\hline $\mathrm{PbO}$ & - & - & - & - & 0.11 & - & - & - & - & - \\
\hline $\mathrm{Na}_{2} \mathrm{O}$ & - & 0.32 & 12.90 & 6.67 & 2.70 & 0.21 & - & 0.09 & Н.обн. & 0.27 \\
\hline $\mathrm{K}_{2} \mathrm{O}$ & - & 10.11 & 0.21 & 1.64 & 5.30 & 6.75 & - & Н.обн. & Н.обн. & 10.54 \\
\hline $\mathrm{Li}_{2} \mathrm{O}$ & - & - & 0.074 & 0.180 & 0.151 & 0.280 & - & - & - & 0.016 \\
\hline $\mathrm{Rb}_{2} \mathrm{O}$ & - & - & 0.001 & 0.010 & 0.360 & 0.021 & - & - & - & 0.042 \\
\hline $\mathrm{Cs}_{2} \mathrm{O}$ & - & - & 0.0004 & 0.0030 & 0.021 & 0.0011 & - & - & - & 0.032 \\
\hline $\mathrm{Nb}_{2} \mathrm{O}_{5}$ & $<0.001$ & - & 0.0170 & 0.0300 & 0.9200 & 0.0039 & 0.001 & 0.6610 & 0.1200 & 0.0090 \\
\hline $\mathrm{Ta}_{2} \mathrm{O}_{5}$ & 0.0001 & - & 0.0001 & 0.0020 & 0.0780 & 0.0010 & 0 & 0.0320 & 0.024 & 0.0010 \\
\hline $\mathrm{P}_{2} \mathrm{O}_{5}$ & - & - & - & Н.обн. & - & - & - & 0.111 & 0.10 & - \\
\hline $\mathrm{H}_{2} \mathrm{O}+$ & - & 2.90 & 0.22 & 1.80 & 3.50 & 3.45 & - & 0.51 & 1.01 & 4.27 \\
\hline $\mathrm{H}_{2} \mathrm{O}-$ & - & - & 0.42 & 0.55 & 0.47 & - & - & - & - & - \\
\hline $\mathrm{F}$ & - & 0.44 & - & 0.75 & 1.16 & 1.15 & - & 0.64 & - & 1.50 \\
\hline$-\mathrm{F}_{2}=\mathrm{O}$ & - & 0.21 & 0.34 & 0.54 & 0.57 & - & 0.31 & - & 0.71 & - \\
\hline Сумма & 99.49 & 99.91 & 100.06 & 100.02 & 99.82 & 99.52 & 100.22 & 99.73 & 99.85 & 99.55 \\
\hline $\mathrm{F}_{\text {общ }}$ & - & 99.60 & 97.00 & 96.70 & 88.40 & 97.60 & - & - & - & 67.60 \\
\hline
\end{tabular}

Примечание: Сл. - следовые значения, н. обн. - не обнаружено, тире - не определялось. Минералы магнетит-аннитовых гранитов: 1 - магнетит; 2 - оранжево-красный и темно-красный аннит; 3-10 минералы эгирин-рибекит-астрофиллитовых гранитов: 3 - светло-зеленый эгирин; 4 - темно-синий рибекит; 5 - золотисто-желтый астрофиллит; 6 - коричнево-красный аннит; 7 - магнетит хромсодержащий; 8 - титанит; 9 - дипирамидальный циркон; 10 - светло-зеленый фенгит. В ан. 8 определена сумма редких земель - 1.99 мас.\%. Анализы выполнены в Центральной химической лаборатории ПО «Уралгеология» (аналитик Н.Ф. Колосова). Li, Rb, Cs - в Полевской химлаборатории ПО «Уралгеология» методом пламенной фотометрии. $\mathrm{F}_{\text {об̆ }}=\mathrm{Fe} /(\mathrm{Fe}+\mathrm{Mg})$. 
Астрофиллит - характерный минерал щелочных гранитов. Отмечен в виде тонких (0.05-0.5 мм) субизометричных пластиночек темно-коричневого цвета, обладающих характерным бронзовым оттенком. Спайность совершенная по (100). Минерал хрупкий. Оптические свойства обычные: $\mathrm{Ng}=1.760 ; \mathrm{Np}=1.715$; двупреломление 0.045. Плеохроизм резкий, от бледно-желто-зеленого или золотистожелтого по $\mathrm{Ng}$ до оранжевого и темнооранжевого по $\mathrm{Np}$. Оптически отрицательный. Химический состав изученногообразца (таблица, обр. 5) близок к составу астрофиллитов из щелочных гранитов массива Кортентас в Центральном Казахстане и ряда аналогичных массивов Дальнего Востока.

Энигматит отмечен только в ассоциации с астрофиллитом в виде спутанноволокнистых и радиально-лучистых темно-коричневых агрегатов. Плеохроизм от коричневого по $\mathrm{Ng}$ до светло-желтого по $\mathrm{Np} ; \mathrm{Ng}>\mathrm{Np}$. Минерал диагностирован рентгенографически (Рентгеновская лаборатория ПО «Уралгеология», аналитик А.Н. Айзикович).

Аннит. Имеет коричнево-красную окраску, высокожелезистый $\left(\mathrm{F}_{\text {общ. }}=96-97\right)$ (таблица, обр. 6), замещает астрофиллит и рибекит. Оптические свойства $(\mathrm{Ng}=1.714$ $1.720 ; \mathrm{Np}=1.679-1.685 ; \mathrm{Ng}-\mathrm{Np}=0.035)$ и политип (1M) изученного образца оказались близкими к характеристикам красных аннитов из эгирин-авгитовых фенитов, сопровождающих кварцевые жилы Кузнечихинского месторождения на Среднем Урале.

Акцессорная минерализация данных гранитов довольно разнообразная и представлена гематитом, рутилом, ильменорутилом, ильменитом-(Nb), пиритом, халькопиритом, молибденитом - 3R, титанитом- $(\mathrm{Nb})$, чевкинитом-(Ce), алланитом$\mathrm{Ce}$ (по чевкиниту), эпидотом-Се (по алланиту), цирконом дипирамидальнымцирконом-(U) длиннопризматическим, апатитом-(F), флюоритом-(Y). В щелочных гранитах Козлиных гор также отмечен колумбит (Тевелев и др., 2015).
Диагностика оптических параметров минералов произведена А.И. Белковским.

\section{Петрогеохимические особенности пород козлиногорского комплекса}

Диаграммы Харкера (рис. 2) дают представление о химическом составе пород КГК. По соотношению кремнезема и суммы щелочей (рис. 3) более основные разности пород попадают в поля субщелочных, редко - щелочных кварцевых сиенитов и граносиенитов, кислые разности адамеллитов и субщелочных гранитов. Наличие специфических цветных минералов (см. выше) позволяет считать породы щелочными. По соотношениям железа и магния породы относятся к производным толеитовых магм, по насыщению глиноземом (ASI) - на границе металюминиевых и пералюминиевых серий. Следует отметить, что по содержаниям $\mathrm{SiO}_{2}$ граносиениты и граниты не образуют непрерывный тренд (рис. 2) - в области 67-70 \% кремнезема наблюдается перерыв. Вероятно, это фазы, немного «оторванные» по времени внедрения. На это также указывают позиция точек на диаграмме Батчелора (рис. 4,a) (Интерпретация...., 2000) и некоторый разрыв возрастов в цирконах из гранитов и габбро (Шардакова, 2015; Тевелев и др., 2015). Для сравнения на диаграммы нанесены точки метаморфитов рамы (гнейсов и гранитогнейсов), которые по составу явно отличаются от пород КГК.

По соотношениям Rb-Sr (Ферштатер, 2013) гранитоиды КГК попадают в поле производных континентальной или островодужной толеитовой магмы. На диаграммах Пирса (рис. 4,б) точки гранитов и граносиенитов КГК пересекают границу субдукционных (VAG) и внутриплитных (WPG) образований, количество точек, попадающих в эти разные поля, делится примерно пополам. Очень часто такое неоднозначное положение имеют породы, формирование которых может быть связано с участием плюмового компонента (Puchkov, 2017).

Сумма РЗЭ и отношения $\mathrm{La} / \mathrm{Yb}$, а так- 
же количество $\mathrm{Sr}$ и U в породах КГК, повидимому, зависят от того, какое количество акцессорных минералов (ортит,

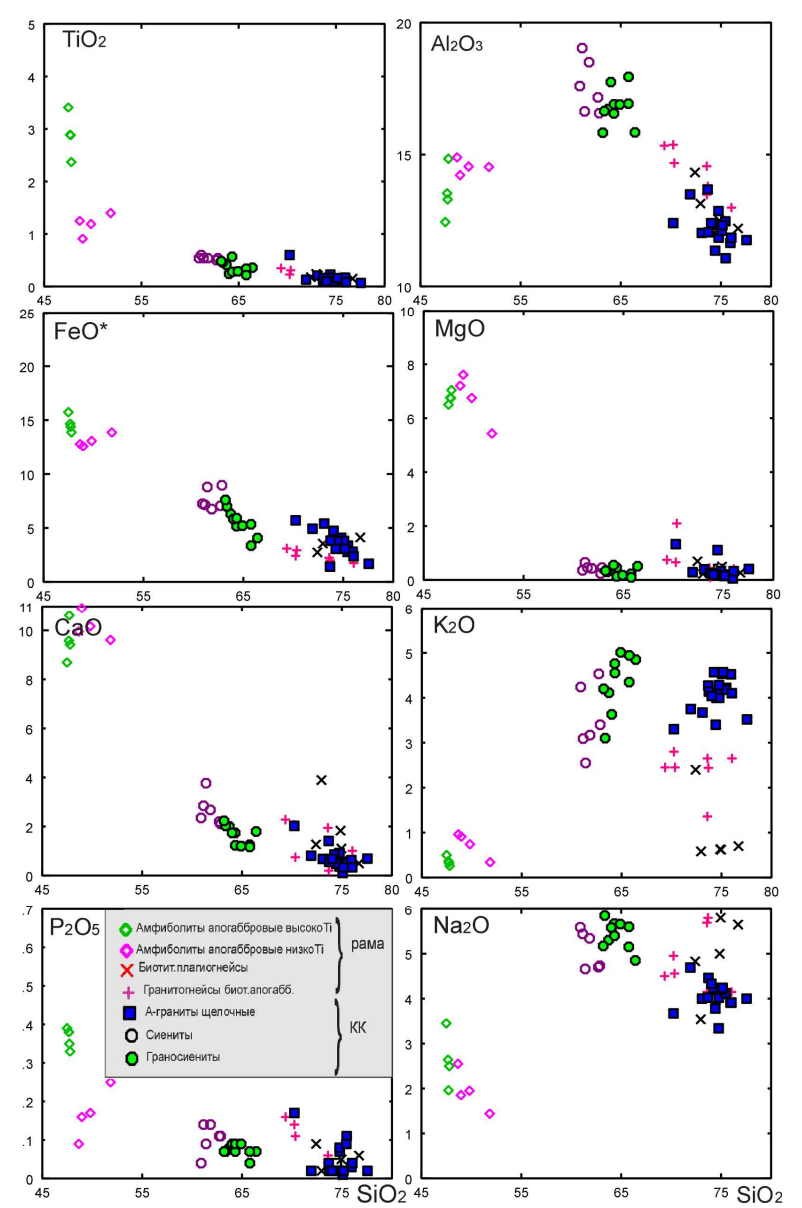

Рис. 2. Диаграммы Харкера для сиенитоидов, гранитов КГК и вмещающих их пород. Все обозначения - на рисунке

апатит, эпидот и др.) попало в пробу, и потому сильно варьируют (отдельные максимумы содержаний на графиках).

В граносиенитах сумма РЗЭ составляет от 24-50 до $170-530$ г/т при $\mathrm{La} / \mathrm{Yb}$ от 8-16 до 600 и выше (в высокостронциевых пробах); в гранитах сумма Р3Э варьирует от 13-25 до 600 г/т, при $\mathrm{La} / \mathrm{Yb}$ от $0.6-4$ до 46. Аномалия европия изменяется от слабой положительной до слабой отрицательной (рис. 5). За счет большого разброса величин граниты и граносиениты по содержаниям РЗЭ (относительно хондрита) образуют широкое общее поле при сохранении конфигурации трендов. На спайдерграммах, нормированных к БСОХ, в гранитах и граносиенитах в основном тренды пород сходны: в них наблюдается отрицательная аномалия Ti, слабые отрицательные - U, Zr, от нулевых до слабых положительных - Ba, Rb, Cs, иногда - Th, и слабые негативные - U, Zr.

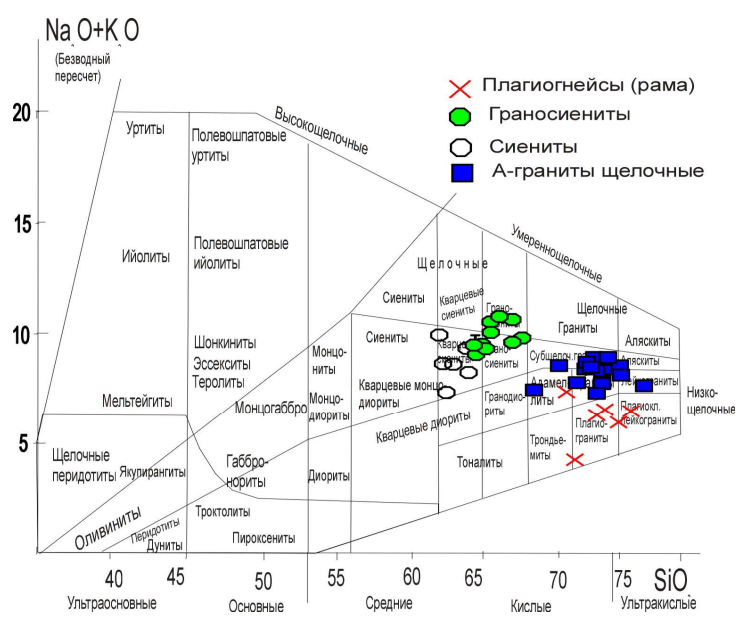

Рис. 3. Классификаиионная диаграмма (Интерпретация..., 2001) суммы щелочей кремнезем для составов пород КК
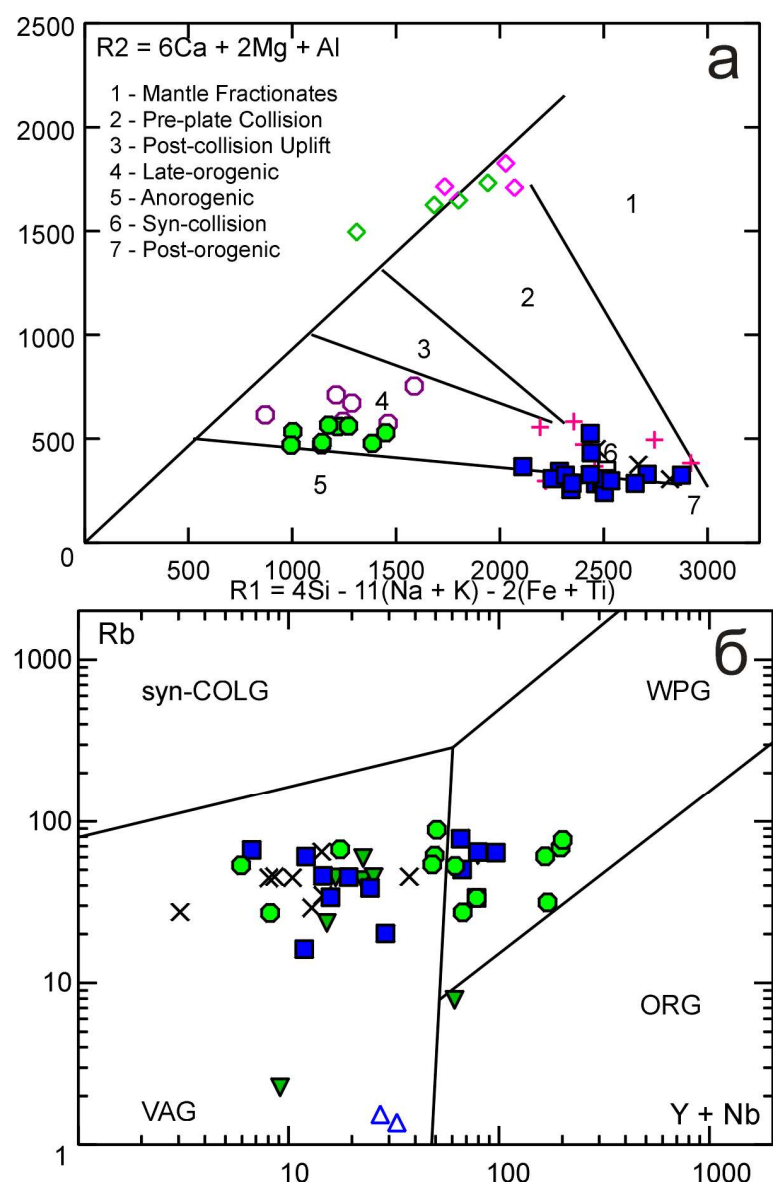

Рис. 4. Геотектонические диаграммы Бэтчелора и Баудена (а) и Пирса (б) (Интерпретаиия..., 2001) для сиенитоидов и гранитов КГК. Условные знаки типов пород см. на рис. 2 
Отличием гранитов и граносиенитов (сиенитов) являются несколько более высокие содержания $\mathrm{Nb}$ в последних. Именно в граносиенитах (или в связи с проходящей через них флюидной фазой) должна быть сосредоточена Nb-минерализация.

Проведенные ранее исследования позволили А.И. Белковскому отнести породы КГК к А-гранитам (Белковский, 2011). Анализ современных петрогеохимических данных подтверждает, что по ряду признаков - повышенным содержаниям $\mathrm{K}_{2} \mathrm{O}$, $\mathrm{Ga}$, железистости, ASI, конфигурации трендов распределения РЗЭ, отрицательным аномалиям $\mathrm{Ti}, \mathrm{Sr}$ (относительно БСОХ) - граниты КГК действительно сходны с эталонными анорогенными гранитами (Whalen et al., 1979; Loiselle, Wones, 1979). На западном склоне близкими характеристиками обладает, например, ряд гранитов из массивов Полярного и Южного Урала, описанных в работах Махлаева (1996, 2008), Кузнецова (2005), Удоратиной и др. (2015), Шардаковой (2008), имеющих среднерифейский или венд-кембрийский возраст и также относимых к А-гранитам. Но имеются и существенные отличия: в частности, породы КГК характеризуются большим количеством $\mathrm{CaO}, \mathrm{Sr}, \mathrm{Ba}$ и меньшим содержанием $\mathrm{Zr}$, Y и суммы $\mathrm{Zr}+\mathrm{Ce}+\mathrm{Y}+\mathrm{Nb}$.

На диаграммы индикаторных соотношений $\mathrm{Y}, \mathrm{Nb}, \mathrm{Zr}$ для редкометалльных гранитных систем (рис. 6) нанесены фигуративные точки гранитов разных этапов развития Урала, имеющих «щелочную» специфику. Это граниты рапакиви Бердяушского плутона (Ронкин и др., 2005), Рябиновского и Губенского массивов (Холоднов и др., 2007) и трахириолитов месторождения Сибирка $\left(\mathrm{R}_{2}\right)$ (Шагалов, Холоднов, 2014), безрудные А-граниты Полярного Урала (Махлаев, 1996, 2008), редкометалльные щелочные граниты месторождения Неудачное (V-C) (Удоратина и др., 2015), субщелочные граниты Уйскоборского массива и Чекинской группы массивов (Магнитогорская зона, возраст 330-300 млн лет) (данные В.В. Холоднова и Д.Н. Салихова), пермские субщелочные граниты Степнинского массива (Ферштатер, 2013).

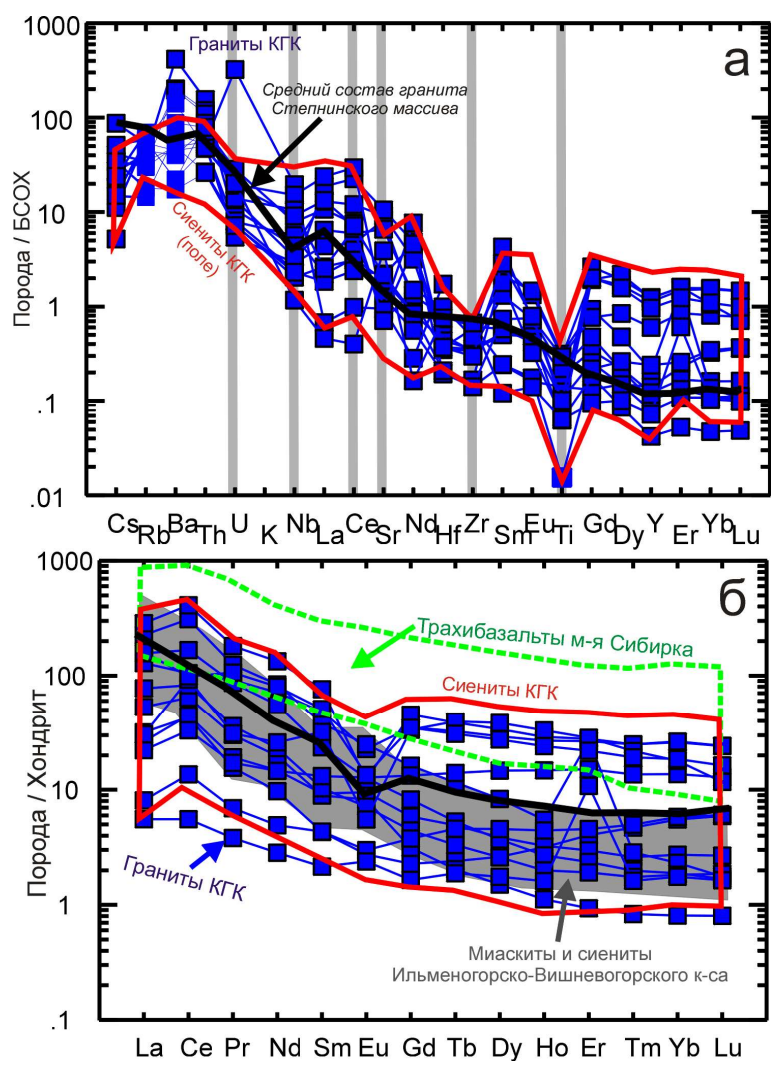

Рис. 5. Нормированное по БСОХ (а) и хондриту (б) (Sun, 1982) распределение элементов-примесей в породах КГК

Также показаны точки средних составов сиенитов и миаскитов Ильменогорско-Вишневогорского комплекса (Недосекова, 2012). Для сравнения показаны средние составы М-, S-, I-, А-гранитов (по Chappel, White, 1974; Whalen et al., 1979; Loiselle, Wones, 1979). Позиция точек пород КГК на этих диаграммах весьма специфична. О чем свидетельствуют петрогеохимические особенности пород КГК?

\section{Обсуждение}

Для гранитоидов КГК сложно найти аналогию по составу и возрасту, и не только среди уральских объектов. Поскольку в данный комплекс входят породы повышенной щелочности, традиционно продуктивные на редкометалльное оруденение, правомерно сравнение с другими известными щелочными комплекса- 
ми Урала (в составе которых часто, как известно, встречаются карбонатиты). КГК пространственно удален от собственно уральских щелочных комплексов, расположенных восточнее зоны ГУР. Наиболее известным является ИльменогорскоВишневогорский комплекс (ИВК) с сиенитами, миаскитами и карбонатитами, приуроченный к микроконтинентальному блоку. Породы ИВК имеют возраст в интервале 450-420 млн лет (Золоев, 2004; Недосекова, 2012), т. е. формировались в ходе того же возрастного и эволюционного этапа, что и КГК, но в другом секторе Урала.

На западном склоне Урала щелочные породы распространены более локально. Самые известные среднерифейские калиевые трахибазальты периферии Тараташского блока (Золоев и др., 2004), нефелиновые сиениты и граниты Бердяуша (Ронкин и др., 2005; Краснобаев и др., 2011), трахириолиты месторождения Сибирка (см. ниже). Образование этих магматитов связано с континентальным рифтогенезом, предшествующим раскрытию Уральского палеоокеана (Холоднов и др., 2006). Ближайшим к нашему объекту является месторождение Сибирка, где руды $\mathrm{Nb}, \mathrm{Ta}$, $\mathrm{Zr}$, Мо ассоциируют с щелочными и карбонатитовыми метасоматитами. По наименее измененным разностям - трахибазальтоидам и щелочным гранитам - ранее приводились датировки 420-387 млн лет (Золоев и др., 2004). По последним данным (Шагалов и др., 2014), вмещающие породы и руды были сформированы в интервале 1395-1337 млн лет (U-Pb и Sm-Nd возрасты), что отвечает этапу машакского рифтогенного события. Последнее, по мнению Пучкова, Эрнста (Пучков, 2012; Ernst, 2014; Puchkov, 2016) и других авторов, связано с эпизодом действия на Ю. Урале рифейского суперплюма, следы которого фиксируются также в Китае, Африке, Америке. Сопоставление показывает (см. рис. 5), что тренды распределения РЗЭ в сходных по основности породах месторождения Сибирка близки с таковыми в породах козлиногорского ком- плекса, но первый объект характеризуется несколько повышенным уровнем содержаний РЗЭ. Распределение РЗЭ в миаскитах ИВК по типу также сходно с такового нашего объекта. Некоторое отличие может быть обусловлено сложным механизмом образования пород ИВК (Недосекова, 2012; Шагалов и др., 2014), включающим специфику субстрата, плюмового компонента, состав поздней флюидной фазы и др. От молодых позднеколлизионных гранитов монцодиорит-гранитного Степнинского массива (Ферштатер, 2013) тренды РЗЭ в породах КГК отличаются поведением ряда важных компонентов.

Анализ диаграмм, ряд из которых приведен на рис. 6, показывает, что, помимо указанного выше сходства с гранитами Атипа и щелочными комплексами, породы КГК имеют специфические особенности. Часть из них описана выше. Отметим здесь пониженные отношения $\mathrm{Zr} / \mathrm{Y}$ (около 1) при относительно высоких в целом содержаниях Y (относительно Zr), сравнительно высокие отношения $\mathrm{Nb} / \mathrm{Y}$ (1-2), повышенные содержания Ba и Sr. При этом породы, генерация которых связана с процессами субдукции и коллизии, имеют совершенно другие (и более узкие) диапазоны соотношений описываемых элементов-примесей. Довольно высокие содержания Y в породах КГК обусловлены, вероятно, присутствием этого элемента в щелочных фемических минералах, поскольку в сиенитах и гранитах не имеется других его носителей и концентраторов. (Исключение составляет флюорит-Ү, который встречается довольно редко и в наших пробах не присутствует.) Выше была изложена точка зрения о мобилизации Y из высокотитанистых амфиболитов на востоке УБ, где проявлены процессы метасоматоза с привносом компонентов и образование оруденения - процесс поздний. В случае с породами КГК, насыщенными специфическими щелочными минералами, которые, скорее всего, образовались из магматического расплава, можно предположить, что и сам субстрат для выплавления магм мог также быть несколько обогащен Y. 
Возрастных и петрогеохимических данных, при отсутствии изотопных параметров, для четких геодинамических интерпретаций не вполне достаточно. На Урале в ордовике имел место спрединг, формирование островных дуг. Для этих образований типичны толеитовые базальты, известково-щелочные андезитоиды с островодужными геохимическими параметрами (Коротеев и др., 2010; Ферштатер, 2013 и др.).

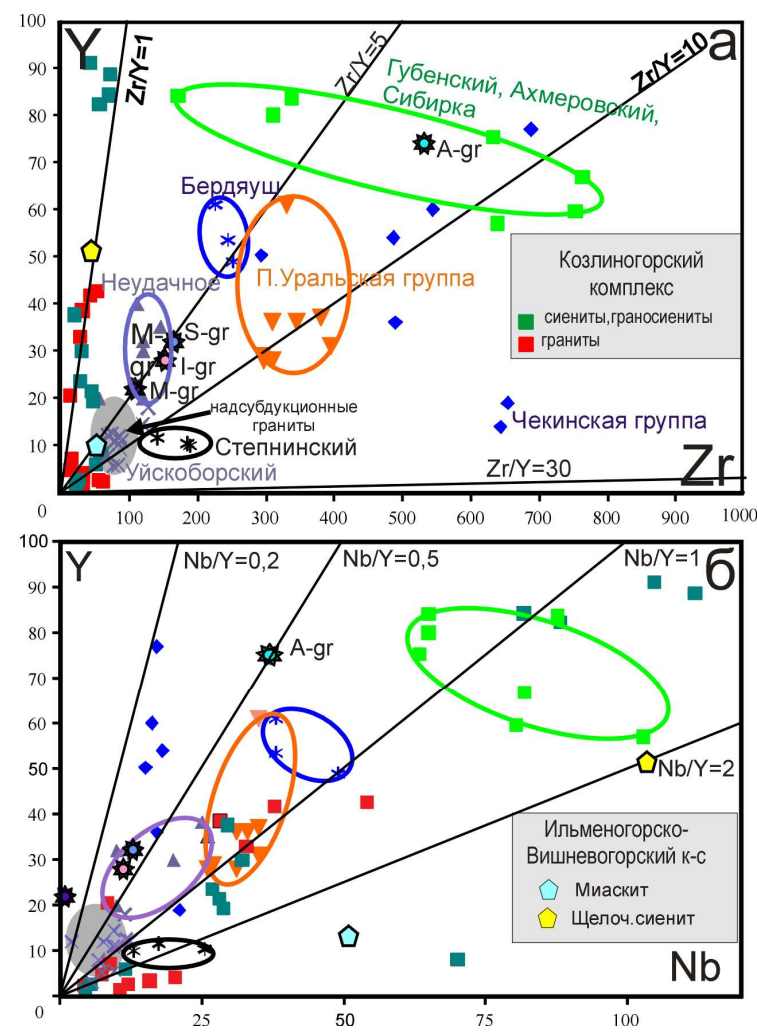

Рис. 6. Соотношения $Z r-Y$ (а) $u$ Nb-Y (б) в породах КГК, а также ряда щелочных комплексов Урала. Все обозначения - на рисунке. Ссылки на работы, из которых взяты анализы пород, приведены в тексте

С другой стороны, поскольку фактически запад УБ - это структура, близкая к краю ВЕП (возможно, ее фрагмент), то внедрение пород ордовикского возраста может отражать некий эпизод тектономагматической активности, связанный с подновленными движениями по ранее существующим рифтовым структурам, т.к. древние породы восточной и центральной частей УБ, возможно, имели среднерифейский возраст (Нечеухин,
Краснобаев, 2000). В это время на западном склоне Урала (Башкирском мегантиклинории) протекали процессы машакского этапа рифтогенеза. Сходной точки зрения придерживаются Коротеев и др. (2010): «Щелочной магматизм нижнего палеозоя... развит в западном и восточном обрамлении уфалейского комплекса, в подновленных долгоживущих рифейских рифтогенных шовных зонах при спредингообразовании Уральского палеоокеана». Определенное сходство пород КГК с типичными А-гранитами и рифтогенными кислыми вулканитами месторождения Сибирка говорит о вероятной связи генезиса КГК с обстановкой растяжения.

Ряд признаков позволяет высказать предположение и об участии в генезисе пород КГК вещества плюма. Косвенными характеристиками наличия в источнике мантийного компонента служат высокие концентрации в породах (особенно в сиенитах) $\mathrm{Sr}, \mathrm{Nb}, \mathrm{Y}$, высокие (>1) отношения последних двух элементов. Положение точек пород КГК на диаграмме Пирса косвенно подтверждает плюмовую природу источника магм, т.к. плюм часто несет группы элементов, одни из которых характерны для субдукционных, а другие для внутриплитных рифтогенных образований (Холоднов и др., 2006; Пучков, 2015), а породы КГК попадают как раз на границы полей (диаграммы на рис. 4).

На рис. 7 приведена диаграмма соотношений $\mathrm{Be}$ и $\mathrm{Nb}$ в породах КГК и других щелочных комплексов Урала (Холоднов, Бушляков, 2010). Видно, что исследуемые нами породы имеют низкие содержания $\mathrm{Be}$ при высоких - $\mathrm{Nb}$, попадая в поле плюм-зависимых образований. Влияние корового компонента по этим параметрам в породах КК практически не прослеживается. Это может свидетельствовать о том, что плюм мог быть не только энергетическим и динамическим инициатором возобновления движений по древним рифтовым разломам в «шовной зоне», но и, в большой мере, - источником вещества. Хотя по поведению ряда других ред- 
ких элементов и особенностям флюидного режима (см. ниже) влияние корового компонента отрицать нельзя.

Одним из авторов было проведено изучение соотношений галогенов, серы, $\mathrm{Sr}$ в цветных и акцессорных минералах граносиенитов и сиенитов КГК (Шардакова, Замятин, 2017).

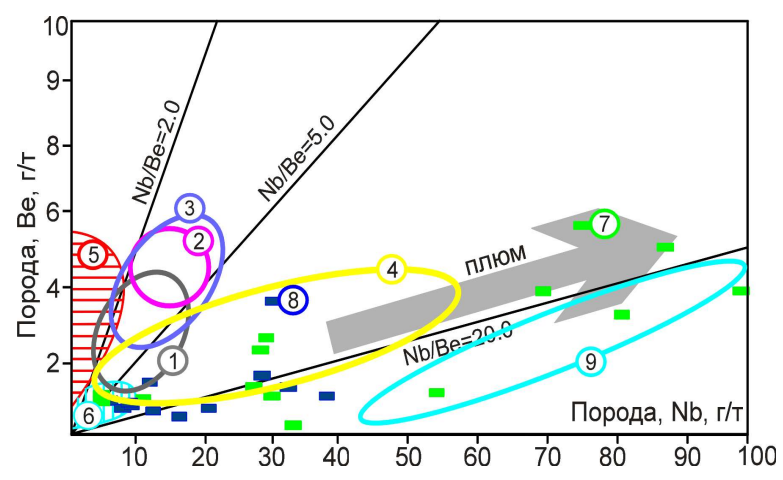

Рис. 7. Соотночения $\mathrm{Nb}$ и Ве в ряде гранитоидных комплексов Урала. Комплексы: 1-3 мурзинского гранитного ареала (южаковский, ватихский, мурзинский); 2 - джабыкский гранитный; 3 - кабанский гранит-лейкогранитовый; 4-степнинский монщодиорит-гранитный (плюм-зависимый, по мнению Пучкова (2017); 5 - еланчикский высокоглинозёмистый (коровый); 6 - поле надсубдукиионных мантийно-коровых гранитов Урала; 7, 8 -козлиногорский комплекс: 7 - щелочные граниты (синие прямоугольники); 8 - граносиениты и сиениты (зеленые прямоугольники). Тип диаграммы и поля комплексов (1-5) - по данным работы Холоднова, Бушлякова (2010). 9 - поле щелочных пород (миаскиты +щелочные сиениты Ильменогорской щелочной полосы, по данным Недосековой (2012)

На диаграмме соотношений $\mathrm{F}-\mathrm{Cl}$ в апатитах точки пород КГК лежат в нижнем поле фторофильных разностей, продуктивных на редкометалльное оруденение (Холоднов, Бушляков, 2010).

Это может указывать на то, что рудоотложения в породах данного типа, вопервых, могли иметь существенно коровую природу и, во-вторых, обогащались редкими металлами в большой мере за счет самих магматических пород. Другая черта щелочных пород КГК - высокие содержания в апатитах (как и в самих грани- тоидах) Sr, что характерно для пород, в генерации которых могло принимать участие вещество плюмов (Холоднов и др., 2010).

Идея об участии плюма в генерации ряда рифтогенных и субдукционных образований подчеркивается в работах Р. Эрнста (Ernst, 2004) и В.Н. Пучкова (2012, 2016 и др.). Отмечено, что серии, в генезисе которых совместно играют роль плейт- и плюм-тектонические процессы, часто имеют «промежуточные» геохимические характеристики, а изотопные метки сдвигаются в сторону мантийных величин в результате плавления континентальной коры под действием плюма, генерированного в верхней мантии. На основе анализа опубликованных нами ранее возрастных и геохимических данных В.Н. Пучков (2015) склоняется к отнесению пород КГК к Ушатскому комплексу, развитому в западном крыле Тараташского антиклинория (Краснобаев и др., 2018). На Северном Урале этот эпизод могут характеризовать сиенит-порфиры верхнесе-

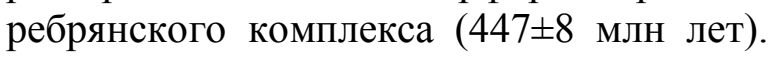
Близкий состав имеют и сиениты Троицкого массива (около 600 млн лет), которые также могут быть связаны с влиянием плюма (Петров и др., 2005). Мировым геохимическим аналогом щелочных пород КГК В.Н. Пучков считает плюмзависимую Монтерегийскую группу щелочных интрузий (Канада), в состав которой, как и в случае с ИВК (восточный склон Урала), как крайний член эволюционного ряда входят карбонатиты.

\section{Заключение}

1. Новые данные по петрогеохимии указывают на принадлежность сиенитоидов и гранитов КГК к щелочным сериям. Наличие и составы щелочных темноцветных минералов (эгирин, рибекит, астрофиллит) из пород КГК подтверждают данную точку зрения.

2. Общий тренд зависимости содержаний большинства компонентов от кремнекислотности указывает на единство гене- 
зиса и сиенитов, и щелочных гранитоидов. Петрогеохимические и возрастные данные позволяют предполагать, что это не непрерывно дифференцированный ряд, а фазы, внедренные с некоторым временным разрывом. Это могло быть связано с относительно длительно функционирующим магматическим источником.

3. Анализ петрогеохимических особенностей свидетельствует о связи магматитов КГК с обстановками растяжения. Предполагается связь щелочных расплавов (и рудогенерирующих флюидов) с мантийным плюмом, который мог быть энергетическим и динамическим источником, инициирующим процесс растяжения по ранее существующим рифтовым трещинам. Он мог также внести вклад в изменение геохимических и изотопных параметров пород КГК, отвечать за присутствие верхнемантийного компонента в субстрате.

4. Щелочные плюм-зависимые серии все чаще идентифицируются на западном склоне Урала, отражая существенную роль плюм-тектонических процессов в геодинамике ранних этапов развития зоны сочленения Урала с ВосточноЕвропейской платформой.

Работа выполнена при финансовой поддержке темы госзадания ИМин УрО РАН, а также в рамках госбюджетной темы ИГГ УpO PAH AAAA-A18-118052590034-0.

\section{Библиографический список}

Белковский А.И. Геология и минералогия кварцевых жил Кыштымского месторождения (Средний Урал) / ИМин УрО РАН. Миасс, 2011. 234 с.

Белковский А.И., Белковская Я.А. Биотиты и вермикулиты Уфалейского метаморфического блока (Средний Урал) / ИМин УрО РАН. Миасс, 2006. 202 с.

Белковский А.И., Локтина И.Н. Раннепалеозойская ассоциация гранитовнефелиновых сиенитов западного склона Среднего Урала // Доклады АН СССР. 1974. T. 215, №5. C. 1206-1209.

Белянкин Д.С., Соколов Г.А. Геологическая карта Урала. Описание листа N-41-I // Tp. Всесоюз. геол.-разв. объед. 1933. Вып. 28. $67 \mathrm{c}$.
Голдин Б.М., Калинин Е.Л., Пучков В.Н. Вендраннепалеозойский магматизм зоны сочленеия Урала и Восточно-Европейской платформы // Вопросы петрологии Урала / ИГГ УНЦ АН СССР. Свердловск, 1980. С. 66-84.

Золоев К.К., Левин В.Я., Мормиль С.И., Шардакова Г.Ю. Минерагения и месторождения редких металлов, молибдена, вольфрама Урала / ИГГ УрО РАН. Екатеринбург, 2004. 336 c.

Кейльман Г.А. Мигматитовые комплексы подвижных поясов. М.: Недра, 1974. 199 с.

Краснобаев А.А., Попов В.С., Беляиякий Б.В. Хронологические и генетические соотношения интрузивных пород Бердяушского плутона (Южный Урал) в свете новых U$\mathrm{Pb}$ и $\mathrm{Sr}-\mathrm{Nd}$ изотопных данных // Зап. Рос. мин. о-ва. 2011. Ч. СХXXX, № 2. С. 59-63.

Краснобаев А.А., Пучков В.Н., Сергеева Н.Д. Полихронная цирконология навышских вулканитов айской свиты (Южный Урал) // Доклады АН. 2018. Т. 478. №1. С. 74-80. doi.org/10.7868/S0869565218010152

Иванов С.Н., Русин А.И. Поздневендский этап тектонического развития Урала // Геотектоника. 2008. № 3. С. 21-31.

Коротеев В.А., Огородников В.Н., Сазонов B.Н., Поленов Ю.А. Минерагения шовных зон Урала / ИГГ УрО РАН. Екатеринбург, 2010. $414 \mathrm{c}$.

Кузнеиов Н.Б., Соболева А.А., Удоратина O.B., Гериева М.B. Доордовикские гранитоиды Тимано-Уральского региона и эволюция протоуралид-тиманид. Сыктывкар: Геопринт, 2005. 97 с.

Интерпретация геохимических данных. М.: Инжиниринг, 2001. 288 с.

Ларин А.М. Граниты рапакиви и ассоциирующие породы. СПб.: Наука, 2011. 402 с.

Ленных В.И. Метаморфические комплексы западного склона Урала / УНЦ АН СССР. Свердловск, 1980. С. 3-70.

Махлаев Л.В. Гранитоиды севера ЦентральноУральского поднятия (Полярный и Приполярный Урал) / УрО РАН. Екатеринбург, 1996. $150 \mathrm{c}$.

Махлаев Л.В. Венд-кембрийские А-граниты севера Урала и предшествующие события геологической истории района // Структурно-вещественные комплексы и проблемы геодинамики докембрийскофанерозойских орогенов. III чтения памяти С.Н.Иванова / ИГГ УрО РАН. Екатеринбург, 2008. С. 78-79. 
Недосекова И.Л. Возраст и источники вещества ильмено-вишневогорского щелочного комплекса (Урал, Россия): геохимические и изотопные $\mathrm{Rb}-\mathrm{Sr}, \mathrm{Sm}-\mathrm{Nd}, \mathrm{U}-\mathrm{Pb}, \mathrm{Lu}-\mathrm{Hf}$ данные // Литосфера. 2012. №5. С. 77-95.

Нечеухин В.М., Краснобаев А.А., Соколов В.Б. Геохронология и структурное положение нижнего докембрия в Уральском аккреционно-складчатом обрамлении Русской плиты // Общие вопросы расчленения докембрия / КНЦ РАН. Апатиты, 2000. С. 201203.

Петров Г.А., Маслов А.В., Ронкин Ю.Л. Допалеозойские магматические комплексы Кваркушско-Каменногорского антиклинория (Средний Урал): новые данные по геохимии и геодинамике // Литосфера. 2005. № 4. С. 42-69.

Пучков В.Н. Геология Урала и Приуралья (актуальные вопросы стратиграфии, тектоники, геодинамики и металлогении). Уфа: Даурия, 2010. $280 \mathrm{c.}$

Пучков В.Н. Геодинамический контроль петрогенетических процессов в уралидах Урала // Магматизм и метаморфизм в истории Земли. XXI Всероссийское петрографическое совещание: тез. докл. / ИГГ УрО РАН. Екатеринбург, 2015. Т. 2 С. 157-158.

Ронкин Ю.Л., Маслов А.В., Матуков Д.И., Пресняков С.Л., Лепихина О.П., Лепихина Г.А. Бердяушский массив: $1350 \pm 10$ млн. лет или древнее? // Ежегодник-2005 / ИГГ УрО РАН. Екатеринбург, 2006. С. 310-314.

Ронкин Ю.Л., Лепихина О.П., Попова О.Ю. Основные геохимические характеристики гранитов-рапакиви и ассоциирующих пород Бердяушского плутона (тектономагматическая позиция и типология) // Ежегодник-2004 / ИГГ УрО РАН. Екатеринбург, 2005. C. 211-219.

Смирнов Г.А. Уфимский амфитеатр. Ч. 1. Стратиграфическое описание. М.: Наука, 1956. $174 \mathrm{c}$.

Скабичевский П.П. О Нижнеуфалейском гранитном массиве // Сов. геология. 1940. №10. C. 106-108.

Тевелев Ал.В., Кошелева И.А., Хотылев А.О., Прудников И.А., Тевелев Арк.В. Новые данные о составе и возрасте козлиногорского комплекса габбро и щелочных гранитов (западный склон Ю.Урала) // Вестн. Моск. ун-та. 2015. Сер. 4. Геология. Вып. 4. С. 74-85.

Удоратина О.В., Андреччев В.Л., Капитанова B.A., Ларионов A.Н. Редкометалльные гра- нитоиды (месторождение Неудачное, Полярный Урал) // Отечественная геология. 2015. № 4. C. 9-16.

Ферштатер Г.Б. Палеозойский интрузивный магматизм Среднего Урала / ИГГ УрО РАН. Екатеринбург, 2013. 368 с.

Холоднов В.В., Ферштатер Г.Б., Бородина Н.С., Шардакова Г.Ю., Прибавкин С.В., Шагалов Е.С., Бочарникова Т.Д. Гранитоидный магматизм зоны сочленения Урала и Восточно-Европейской платформы (Южный Урал) // Литосфера. 2006. № 3. С. 3-28.

Холоднов В. В., Шагалов Е. С., Коновалова $E$. $B$. Геохимия апатита в интрузивных породах Урала, характеризующихся различной рудной специализацией // Ежегодник2009. Тр. ИГГ УрО РАН. 2010. Вып. 157. C. $190-195$.

Шагалов Е.С., Холоднов В.В., Носова А.А. К вопросу о возрасте вмещающих пород редкометалльного месторождения Сибирка: $\mathrm{Sm}-\mathrm{Nd}-$ и $\mathrm{U}-\mathrm{Pb}$ (циркон) изотопные данные // Ежегодник-2013. Тр. ИГГ УрО РАН. Екатеринбург, 2014. Вып. 161. С. 362-366.

Шардакова Г.Ю. Новые данные по петрогеохимии Ахмеровского гранитного массива // Вестник Уральского отделения РМО. 2008. №5. C. 111-120.

Шардакова. Г.Ю., Савельев В.П., Пужаков Б.А., Петров В.И. Новые данные о химическом составе и возрасте пород козлиногорского комплекса // Ежегодник-2014. Тр. ИГГ УрО РАН. Екатеринбург, 2015. Вып. 162. C. $148-154$.

Шардакова Г.Ю. Гранитоиды Уфалейского блока: геодинамические обстановки, возраст, источники, проблемы // Литосфера. 2016. № 4. C. 133-137.

Шардакова Г.Ю., Замятин Д.А. Поведение галогенов и серы в гидроксилсодержащих минералах из гранитоидов западного склона Среднего Урала как показатель потенциальной продуктивности рудномагматических систем // Ежегодник-2016. Тр. ИГГ УрО РАН. Екатеринбург, 2017. Вып. 164.С. 193-198.

Chappell B. W., White A. J. R. Two contrasting granite types // Pacific Geology. 1974. Vol. 8. P. 173-174.

Ernst R.E. Large Igneous Provinces. Cambridge Univ. Press, 2014. 683 p.

Loiselle M. C., Wones D. S. Characteristics and origin of anorogenic granites // Geol. Soc. America. Abstracts and Programs. 1979. Vol. 
11. P. 468.

Puchkov V.N. Relationship between plume and plate tectonics // Geotectonics. 2016. Vol. 50, V. 4. P. 425-438. doi.org/10.1134 /S0016852116040075

Sun S.-S. Chemical composition and origin of the Earth's primitive mantle // Geochim. Cosmo- chim. Acta. 1982. Vol. 46. P.179-192.

Whalen J.B., Currle K.L., Chappell B.W. A-type granites: Geochemical characteristics, discrimination and petrogenesis // Geol. Soc. of America. Abstract with Programs. 1979. 539 p.

\title{
New Data on Mineralogy and Petrogeochemistry of Alkaline Rocks of the Kozlinogorsk Complex: Ufaley Block, Middle Urals
}

\author{
A.I. Belkovsky ${ }^{1}$, G.Yu. Shardakova ${ }^{2}$, V.V. Kholodnov ${ }^{2}$, V.N. Udachin ${ }^{1}$, \\ E.V. Konovalova ${ }^{2}$ \\ ${ }^{1}$ Institute of Mineralogy, Ural Branch of the Russian Academy of Sciences, 1 Ilmenskiy \\ Zapovednik Str., Miass 456317, Russia \\ ${ }^{2}$ Institute of Geology and Geochemistry, Ural Branch of the Russian Academy of Sciences, 15 \\ Akad. Vonsovskogo Str., Ekaterinburg 620016, Russia \\ E-mail: shardakova@igg.uran.ru
}

Rare metals bearing alkaline complexes are quite uncommon on the western slope of the Urals. The Kozlinogorskiy complex is situated in the Ufaley block related to the junction zone of the Urals and the East European Platform. Gabbro, syenites, granosyenites and granites comprise the complex. Their alkaline nature is proved by the presence of aegirine, riebeckite, astrophyllite, enigmatite. Rocks are characterized by the ratio of rare elements and fluid regime features indicating the participation of the mantle plume in their genesis. The plume formation could be an energy and material source that initiated the process of reopening of the ancient rift structure. Alkaline plume-dependent series on the western slope of the Urals have been recorded more frequently last time, indicating the significant role of plume tectonics in the geodynamics of the early stages of the structure evolution.

Key words: alkaline complex; rare metal mineralization; rifting; orogenic granites; petrogeochemistry; plume tectonics.

\section{References}

Belkovskiy A.I. 2011. Geologiya i mineralogiya kvartsevykh zhil Kyshtymskogo mestorozhdeniya (Sredniy Ural) [Geology and mineralogy of quartz veins of the Kyshtym deposit (Middle Urals)]. Miass, IMin UrO RAN, p. 234. (in Russian)

Belkovskiy A.I.,Belkovskaya Ya.A. 2006. Biotity i vermikulity Ufaleyskogo metamorficheskogo bloka (Sredniy Ural) [Biotite and vermiculite of the Ufaley metamorphic block]. Miass, IMin UrO RAN, p. 202. (in Russian)

Belkovskiy A.I., Loktina I.N. 1971. Otchet o rezultatakh poiskovykh rabot na redkie metally po otsenke tantalonosnosti zapadnoy chasti ufaleyskogo gneysovo-migmatitovogo kompleksa, provedennyy v 1969-1970 gg. v Ufaleyskom i Kyshtymskom rayonakh Chelyabinskoy oblasti (Report on the results of prospecting for rare metals based on assessment of the Tantalum occurrence on the western part of the Ufaley gneiss-migmatite complex, carried out in 1969-1970 in the Ufaley and Kyshtymskiy districts of the Chelyabinsk region]. Chelyabinsk, Geolfondy ChGRE, p. 210. (in Russian)

Belkovskiy A.I., Loktina I.N. 1974. Rannepaleozoiskaya assotsiatsiya granitov-nefelinovykh sienitov zapadnogo sklona Srednego Urala [Early Paleozoic association of granitesnepheline syenite from the western slope of 
the Middle Urals]. DAN SSSR, 215(5): 1206-1209. (in Russian)

Belyankin D.S., Sokolov G.A. 1933. Geologicheskaya karta Urala. Opisanie lista N-41-I [Geologocal map of the Urals. Description of Sheet N-41-I]. Tr. Vsesoyuzn. Geol.-razv. Obyed., 28, p. 67. (in Russian)

Goldin B.M., Kalinin E.L., Puchkov V.N. 1980. Vend-rannepaleozoyskiy magmatizm zony sochleneniya Urala i VostochnoEvropeyskoy platformy [Vendian-Early Paleosoic magmatism of the junction zone between the Urals and the East European Platform]. Voprosy petrologii Urala. Sverdlovsk, p. 66. (in Russian)

Zoloev K.K., Levin V.Ya., Mormil S.I., Shardakova G.Yu. 2004. Minerageniya i mestorozhdeniya redkikh metallov, molibdena, volframa Urala [Mineragenia and deposits of the rare metals, molybdenum, and tungsten of Urals]. Ekaterinburg, IGG UrO RAN, p. 336. (in Russian)

Keylman G.A. 1974. Migmatitovye kompleksy podvizhnykh poyasov [Migmatite complexes of the mobile belts]. Moskva, Nedra, p. 199. (in Russian)

Krasnobaev A.A., Popov V.S., Belyatskiy B.V. 2011. Khronologicheskie i geneticheskie sootnosheniya intruzivnykh porod Berdyaushskogo plutona (Yuzhnyy Ural) v svete novykh U-Pb i Sr-Nd izotopnykh dannykh [Chronological and genetic relations of the intrusive rocks of the Berdyaush pluton (South Urals) in the light of the new U-Pb and $\mathrm{Sr}-\mathrm{Nd}$ isotope data]. ZRMO. CXXXX (2):59. (in Russian)

Krasnobaev A.A., Puchkov V.N., Sergeeva N.D. 2018. Polikhronnaya tsirkonologiya navyshskikh vulkanitov ayskoy svity (Yuzhnyy Ural) [Polichronous zirconology of the Navysh volcanic rocks of the Ay Suite (South Urals)]. Doklady AN. 478(1):74-80. (in Russian) doi: $10.7868 / \mathrm{S} 0869565218010152$

Ivanov S.N., Rusin A.I. 2008. Pozdnevendskiy etap tektonicheskogo razvitiya Urala [Upper Vendian stage of the tectonic evolution of the Urals]. Geotektonika, 3:21-31. (in Russian)

Koroteev V.A., Ogorodnikov V.N., Sazonov V.N., Polenov Yu.A. 2010. Minerageniya shovnykh zon Urala [Minerageny of the suture zone of the Urals]. Ekaterinburg, IGG UrO RAN, p. 414. (in Russian)

Kuznetsov N.B., Soboleva A.A., Udoratina O.V, Gertseva M.V. 2005. Doordovikskie granitoidy Timano-Uralskogo regiona i evolyutsi- ya protouralid-timanid [Pre-Ordovician granites of the Timan-Uralian region and the evolution of the protouralides-timanides]. Syktyvkar, Geoprint, p. 97. (in Russian)

Interpretatsiya geokhimicheskikh dannykh. [Interpretation of the geochemical data]. Moskva, Inzhiniring, 2001, p. 288. (in Russian)

Larin A.M. 2011. Granity rapakivi i assotsiiruyushchie porody [Rapakivi granites and associated rocks]. Spb, Nauka, p. 402. (in Russian)

Lennykh V.I. 1980. Metamorficheskie kompleksy zapadnogo sklona Urala (Metamorphic complexes of the western slope of the Urals). Sverdlovsk, UNC AN SSSR, pp. 3-70. (in Russian)

Makhlaev L.V. 1996. Granitoidy severa Tsentralno-Uralskogo podnyatiya (Polyarnyy i Pripolyarnyy Ural) [Granitoids of the Central Uralian Uplift (Polar and Cis-Polar Urals)]. Ekaterinburg, UrO RAN, p. 150. (in Russian)

Makhlaev L.V. 2008. Vend-kembriyskie A granity severa Urala i predshestvuyushchie sobytiya geologicheskoy istorii rayona [Vendian-Cambrian A-granites of the Northern Urals and predicted events of the geological evolution of the region]. In: Strukturnoveshchestvennye kompleksy i problemy geodinamiki dokembriysko-fanerozoyskikh orogenov. III chteniya pamyati S.N. Ivanova. Ekaterinburg, IGG UrO RAN, pp. 78-79. (in Russian)

Nedosekova I.L. 2012. Vozrast i istochniki veshchestva ilmeno-vishnevogorskogo shchelochnogo kompleksa (Ural, Rossiya): geokhimicheskie i izotopnye $\mathrm{Rb}-\mathrm{Sr}, \mathrm{Sm}-\mathrm{Nd}$, $\mathrm{U}-\mathrm{Pb}, \mathrm{Lu}-\mathrm{Hf}$ dannye [The age and the material sources for the IlmenogorskVishnevogorsk alkaline complex (Urals, Russia): geochemical and isotope $\mathrm{Rb}-\mathrm{Sr}$, Sm-Nd, U-Pb, Lu-Hf data]. Litosfera, 5: 77-95. (in Russian)

Necheukhin V.M., Krasnobaev A.A., Sokolov V.B. 2000. Geokhronologiya i strukturnoe polozhenie nizhnego dokembriya $\mathrm{v}$ Uralskom akkretsionno-skladchatom obramlenii Russkoy plity [Geochronology and structural position of the Lower Precambrian in the Uralian accretion folded boundary of the Russian Plate]. In: Obshchie voprosy raschleneniya dokembriya. Apatity, KNC RAN, pp. 201203. (in Russian)

Petrov G.A., Maslov A.V., Ronkin Yu.L. 2005. Dopaleozoyskie magmaticheskie kompleksy Kvarkushsko-Kamennogorskogo anti- 
klinoriya (Srednij Ural): novye dannye po geokhimii i geodinamike [Pre-Paleosoic magmatic complexes of the KvarkushKamennogorsk antikline (Middle Urals): a new geochemical and geodynamical data]. Litosfera, 4:42-69. (in Russian)

Puchkov V.N. 2010. Geologiya Urala i Priuralya (aktualnye voprosy stratigrafii, tektoniki, geodinamiki i metallogenii) [Geology of the Urals and Cis-Urals: actual problems of stratigraphy, tectonics, geodynamics and metallogeny]. Ufa, Dauriya, p. 280 (in Russian)

Puchkov V.N. 2015. Geodinamicheskiy kontrol petrogeneticheskikh protsessov $\mathrm{v}$ uralidakh Urala [Geodynamical control of the petrogenetic processes in the uralides of the Urals]. In: Magmatizm i metamorfizm $\mathrm{v}$ istorii Zemli. XXI Vserossiyskoe petrograficheskoe soveshchanie. Tez. dokl. T. 2. Ekaterinburg, IGG UrO RAN, pp. 157-158. (in Russian)

Ronkin Yu.L., Maslov A.V., Matukov D.I., Presnyakov S.L., Lepikhina O.P., Lepikhina G.A. 2006. Berdyaushskiy massiv: $1350 \pm 10$ mln. let ili drevnee? (Berdyaush massif: $1350 \pm 10 \mathrm{Ma}$ or older?). Ezhegodnik-2005. Ekaterinburg, IGG UrO RAN, pp. 310-314. (in Russian)

Ronkin Yu.L., Lepikhina O.P., Popova O.Yu. 2005. Osnovnye geokhimicheskie kharakteristiki granitov-rapakivi i assotsiiruyushchikh porod Berdyaushskogo plutona (tektonomagmaticheskaya pozitsiya i tipologiya) [The main geochemical features of the Berdyaush pluton's rocks (tectonomagmatic position and typization)]. Ezhegodnik-2004. Ekaterinburg, IGG UrO RAN, pp. 211-219. (in Russian)

Smirnov G.A. 1956. Ufimskiy amfiteatr Ch. 1. Stratigraficheskoe opisanie. [Ufimskiy Amphitheatre. T.1. Stratigraphic description]. Moskva, Nauka, p. 174. (in Russian)

Skabichevskiy P.P. 1940. O Nizhneufaleyskom granitnom massive [About the Nizhneufaley granite massif]. Sov. Geologiya, 10:106-108. (in Russian)

Tevelev Al.V., Kosheleva I.A., Khotylev A.O., Prudnikov I.A., Tevelev Ark.V. 2015. Novye dannye o sostave i vozraste kozlinogorskogo kompleksa gabbro i shchelochnykh granitov (zapadnyy sklon Yu.Urala) [A new data about composition and age of the gabbro and alkaline granites of the Kozlinogorsk Complex (western slope of the Urals)]. Vestn. Mosk. Univ., Ser. Geologiya, 4: 74-85. (in Russian)
Udoratina O.V., Andreichev V.L., Kapitanova V.A., Larionov A.N. 2015. Redkometallnye granitoidy (mestorozhdenie Neudachnoe, Polyarnyy Ural) [Rare metal granites (Neudachnoe deposit, Polar Urals)]. Otechestvennaya geologiya, 4: 9-16. (in Russian)

Fershtater G.B. 2013. Paleozoryskiy intruzivnyy magmatizm Srednego Urala [Paleosoic intrusive magmatism of the Middle Urals]. Ekaterinburg, IGG UrO RAN, p. 368. (in Russian)

Kholodnov V.V., Fershtater G.B., Borodina N.S., Shardakova G.YU., Pribavkin S.V., Shagalov E.S., Bocharnikova T.D. 2006. Granitoidnyy magmatizm zony sochleneniya Urala i Vostochno-Evropeyskoy platformy (Yuzhnyy Ural) [Granitoid magmatism of the junction zone between the Urals and EasternEuropean Platform (South Urals)]. Litosfera, 3: 3-28. (in Russian)

Kholodnov V. V., Shagalov E. S., Konovalova E. V. 2009. Geokhimiya apatita v intruzivnykh porodakh Urala, kharakterizuyushchihsya razlichnoy rudnoy spetsializatsiey (Geochemistry of apatite in the Uralian intrusive rocks of the different ore specialization). Ezhegodnik-2009. Tr. IGG UrO RAN, 157: 190-195. (in Russian)

Shagalov, E.S., Kholodnov V.V., Nosova A.A. 2014. K voprosu o vozraste vmeshchayushchikh porod redkometallnogo mestorozhdeniya Sibirka: $\mathrm{Sm}-\mathrm{Nd}-\mathrm{i}$ U-Pb (cirkon) izotopnye dannye [About problem of the age of rare metal Sibirka deposit: $\mathrm{Sm}-\mathrm{Nd}$ and $\mathrm{U}-$ $\mathrm{Pb}$ (zirkon) isotope data]. Ezhegodnik-2013. Tr. IGG UrO RAN, 161: 362-366. (in Russian)

Shardakova G.Yu. 2008. Novye dannye po petrogeokhimii Akhmerovskogo granitnogo massiva [New data about petrogeochemistry of the Akhmer massif]. Vestnik Uralskogo otdeleniya RMO. 5: 111-120. (in Russian)

Shardakova. G.Yu., Saveliev V.P., Puzhakov B.A., Petrov V.I. 2015. Novye dannye o khimicheskom sostave i vozraste porod kozlinogorskogo kompleksa [New data about chemical composition and age of rocks from Kozlinogorsk Complex]. Ezhegodnik-2014. Trudy IGG UrO RAN, 162: 148-154. (in Russian)

Shardakova G.Yu. 2016. Granitoidy Ufaleyskogo bloka: geodinamicheskie obstanovki, vozrast, istochniki, problemy [Granitoids of the Ufaley bliock: geodynamic setting, age, sources, problems]. Litosfera, 4: 133137. (in Russian) 
Shardakova G.Yu., Zamyatin D.A. 2017. Povedenie galogenov i sery $\mathrm{v}$ gidroksilsoderzhashchikh mineralakh iz granitoidov zapadnogo sklona srednego urala kak pokazatel potentsialnoy produktivnosti rudnomagmaticheskikh sistem [Behavior of halogens and sulfur in hydroxyl-bearing minerals from granites of the western slope of the Urals as an indicator of the potential productivity of ore-magmatic systems]. Ezhegodnik-2016. Tr. IGG UrO RAN, 164: 193-198. (in Russian)

Chappell B. W., White A. J. R. 1974. Two contrasting granite types. Pacific Geology, 8: 173-174.

Ernst R.E. 2014. Large Igneous Provinces. Cam- bridge Univ. Press, p. 683.

Loiselle M. C., Wones D. S. 1979. Characteristics and origin of anorogenic granites. Geol. Soc. America. Abstracts and Programs, 11: 468.

Puchkov V.N. 2016. Relationship between plume and plate tectonics. Geotectonics, 50(4): 425-438. doi.org/10.1134/S0016852116040075

Sun S.-S. 1982. Chemical composition and origin of the Earth's primitive mantle. Geochim. Cosmochim. Acta, 46: 179-192.

Whalen J.B., Currle K.L., Chappell B.W. 1979. A-type granites: Geochemical characteristics, discrimination and petrogenesis. Geol. Soc. of America. Abstract with Programs, p. 539. 